\title{
Multiple Users Round Trip Time CDF Probability Models in IEEE802.11b WLANS
}

\section{OGHOGHO, I}

\author{
Department of Electrical/Electronic Engineering, Delta State University, Abraka, Delta State, Nigeria \\ Corresponding Author Email: oghogho.ikponmwosa@delsu.edu.ng,oghoghoik@gmail.com
}

\begin{abstract}
Multiple Users Round Trip Time Cumulative Distribution Function Probability Models (MURTTCDFPM) in IEEE 802.11b Wireless Local Area Networks (WLANs) have been presented in this paper. To develop the models, field and validation data were collected for various Quality of service (QoS) traffic in three different environments namely: open corridor, small offices and free space for an infrastructure based IEEE802.11b WLAN. The data was categorised into four signal ranges namely: all signals considered, strong signals, grey signals and weak signals. By assuming a normal distribution for the collected field data, MURTTCDFPM were developed and correction factors were applied to improve their prediction accuracy. The MURTTCDFPM developed were compared with existing Single user Round trip time (RTT) Cumulative distribution function (CDF) probability models. The results and the tests conducted show that the MURTTCDFPM have good performances as root mean square (RMS) errors $<11.9274495 \%$ were observed.
\end{abstract}

\section{DOI:https://dx.doi.org/10.4314/jasem.v23i3.20}

Copyright: Copyright (C) 2019 Oghogho. This is an open access article distributed under the Creative Commons Attribution License (CCL), which permits unrestricted use, distribution, and reproduction in any medium, provided the original work is properly cited.

Dates: Received: 11 January 2019; Revised: 21 February 2019; Accepted 22 March 2019

Keywords: Round Trip Time, Signal to Noise Ratio, Probability models, IEEE802.11b, WLANs

The round trip time (RTT) is one of the most important metrics for determining the performance of data networks (Geier, 2008a). A maximum acceptable RTT limit is imposed on a wireless local area network (WLAN) if it is to be accepted to have provided sufficient and efficient coverage (Geier, 2008b). RTT is the time required for a signal pulse or packet to travel from a specific source to a specific destination and back again (Ali and Khuder, 2012). RTT can range from just a few milliseconds under excellent conditions (high SNR, short distance between transmitter and receiver, etc.) to several seconds when conditions become adverse (weak SNR, large distance between transmitter and receiver, congestion due to multiple users, etc.). Network designers and installers are in need of tools that help them to reliably predict the RTT and several important network metrics (like the throughput) so as to aid and enable fast and reliable decisions during design, installation or maintenance. During network design and installation one of the metrics easily measured is the received signal strength indication (RSSI) from which the signal to noise ratio is computed. Being able to predict the RTT directly from the measured RSSI will therefore be very useful.

Several work including Kavidha and Sadasivam (2010), Domenico and Stefan, (2011), Zobenko et al, (2014), Li et al., (2009), El Miloud, et al. (2013), Stephen, (2013), Nafei et al., (2013) have extensively studied the RTT and some have provided RTT models. However none of these researches directly predict RTT from the SNR computed from the received signal strength indication (RSSI) observed. Can the RTT be directly and reliably predicted from the computed SNR so as to make the prediction process easier?

Several research has shown that throughput in WLANs can be predicted directly from the SNR with reasonable accuracy (Henty, (2001); Oghogho et al., (2014a); Oghogho et al., (2014b), Oghogho et al.,(2015a), Oghogho et al., (2015b), Oghogho, (2017), Oghogho et al., (2017), Oghogho et al., (2018). Among these researches, Oghogho et al, (2014b) and Oghogho, et al, (2015a) provided throughput CDF probability models based on different ranges of SNR observed. These throughput probability models help to predict the probability that the throughput observed will fall into a particular range of value based on the category of signal (strong, grey or weak signal).

In a similar way Oghogho (2018) provided single user RTT models that could directly predict RTT from the observed SNR for an IEEE 802.11b WLAN. These models were however not probability models. Oghogho (2019) provided single user RTT CDF probability models which can be used to predict the probability that RTT falls within a certain range for 
different ranges of SNR. However to the best of the author's knowledge, no multiple users RTT probability models based on observed SNR only exists. This paper is focused to fill this gap.

\section{MATERIALS AND METHOD}

The method used in Oghogho, et al., (2014a), Oghogho et al., (2014b) and Oghogho (2019) was also used in this work except that RTT multiple users data was collected instead of throughput data. The multiple users RTT data collected were categorized into four categories using the SNR namely: (i) All signals considered, (ii) Strong signals only ( $\mathrm{SNR}>25 \mathrm{~dB}$ ), (iii) Grey signals only $(25 \mathrm{~dB}>\mathrm{SNR}>18 \mathrm{~dB})$ (iv) Weak signals only $(\mathrm{SNR}<19 \mathrm{~dB})$ only. MURTTCDFPM for each SNR category to which correction factors were applied were developed by assuming a normal distribution to the collected RTT field data. The MURTTCDFPM can predict the probability that RTT falls into different RTT ranges for various SNR considered for multiple users on the network. The number of users was limited to seven users due to the work of $\mathrm{Wu}$ et al. (2011) where seven users represented saturation traffic where each client always has a packet to send.Validation data was collected using the method used by Oghogho (2019). The models were compared with the validation data and the RMS errors were computed and used to test the performances of the models.

\section{RESULTS AND DISCUSSION}

Table 1 shows the computed empirical multiple users RTT field data probabilities for the different SNR categories while Table 2 shows other statistical parameters of the RTT multiple users field data. As can be seen from Table 1, the multiple user probabilities vary considerably for the different SNR categories in the respective RTT ranges. For all the signal categories considered, the probability of obtaining a RTT value $<$ $1 \mathrm{~ms}$ is $0 \%$ for multiple users. Also worthy of mentioning is in the weak signal range where the probability of obtaining a RTT $<7 \mathrm{~ms}$ is $0 \%$ implying that when the signal becomes weak, the RTT increases considerably for multiple users. From Table 2, the smallest RTT mean (148.437147ms), standard deviation (322.1813368ms) and variance (103800.814) were observed when all signals were strong.

\begin{tabular}{|c|c|c|c|c|c|}
\hline RTT (ms) & $\begin{array}{l}\text { Statistical } \\
\text { Parameter }\end{array}$ & ALL (SNR) & $\begin{array}{l}\text { Strong } \\
\text { Signal } \\
\end{array}$ & Grey signal & $\begin{array}{l}\text { Weak } \\
\text { Signal } \\
\end{array}$ \\
\hline$>2000$ & $\begin{array}{l}\text { Frequency } \\
\text { Probability }\end{array}$ & $\begin{array}{l}14 \\
0.0075922\end{array}$ & $\begin{array}{l}6 \\
0.0041351\end{array}$ & $\begin{array}{l}6 \\
0.0165746\end{array}$ & $\begin{array}{l}3 \\
0.09375\end{array}$ \\
\hline $1000-1999.99$ & $\begin{array}{l}\text { Frequency } \\
\text { Probability }\end{array}$ & $\begin{array}{l}31 \\
0.0168113\end{array}$ & $\begin{array}{l}9 \\
0.0062026\end{array}$ & $\begin{array}{l}22 \\
0.0607735\end{array}$ & $\begin{array}{l}0 \\
0.0000\end{array}$ \\
\hline $500-999.99$ & $\begin{array}{l}\text { Frequency } \\
\text { Probability }\end{array}$ & $\begin{array}{l}70 \\
0.037961\end{array}$ & $\begin{array}{l}34 \\
0.0234321\end{array}$ & $\begin{array}{l}35 \\
0.0966851\end{array}$ & $\begin{array}{l}2 \\
0.0625\end{array}$ \\
\hline $100-499.99$ & $\begin{array}{l}\text { Frequency } \\
\text { Probability } \\
\text { Frequency }\end{array}$ & $\begin{array}{l}769 \\
0.4170282 \\
326\end{array}$ & $\begin{array}{l}584 \\
0.402481 \\
264\end{array}$ & $\begin{array}{l}168 \\
0.4640884 \\
56\end{array}$ & $\begin{array}{l}14 \\
0.4375 \\
8\end{array}$ \\
\hline $50-99.99$ & $\begin{array}{l}\text { Probability } \\
\text { Frequency } \\
\text { Probability }\end{array}$ & $\begin{array}{l}0.1767896 \\
255 \\
0.1382863\end{array}$ & $\begin{array}{l}0.1819435 \\
214 \\
0.1474845\end{array}$ & $\begin{array}{l}0.1546961 \\
38 \\
0.1049724\end{array}$ & $\begin{array}{l}0.25 \\
4 \\
0.125\end{array}$ \\
\hline $10-19.99$ & $\begin{array}{l}\text { Frequency } \\
\text { Probability }\end{array}$ & $\begin{array}{l}122 \\
0.0661605\end{array}$ & $\begin{array}{l}114 \\
0.0785665\end{array}$ & $\begin{array}{l}8 \\
0.0220994\end{array}$ & $\begin{array}{l}0 \\
0.00000\end{array}$ \\
\hline $7-9.99$ & Frequency & 48 & 29 & 17 & 1 \\
\hline $6-6.99$ & $\begin{array}{l}\text { Probability } \\
\text { Frequency }\end{array}$ & $\begin{array}{l}0.0260304 \\
23\end{array}$ & $\begin{array}{l}0.0199862 \\
23\end{array}$ & $\begin{array}{l}0.0469613 \\
0\end{array}$ & $\begin{array}{l}0.03125 \\
0\end{array}$ \\
\hline $5-5.99$ & $\begin{array}{l}\text { Probability } \\
\text { Frequency } \\
\text { Probability }\end{array}$ & $\begin{array}{l}0.0124729 \\
30 \\
0.016269\end{array}$ & $\begin{array}{l}0.0158511 \\
27 \\
0.0186079\end{array}$ & $\begin{array}{l}0.0000 \\
3 \\
0.0082873\end{array}$ & $\begin{array}{l}0.00000 \\
0 \\
0.000000\end{array}$ \\
\hline $4-4.99$ & $\begin{array}{l}\text { Frequency } \\
\text { Probability }\end{array}$ & $\begin{array}{l}41 \\
0.0222343\end{array}$ & $\begin{array}{l}39 \\
0.026878\end{array}$ & $\begin{array}{l}2 \\
0.0055249\end{array}$ & $\begin{array}{l}0 \\
0.00000\end{array}$ \\
\hline $3-3.99$ & $\begin{array}{l}\text { Frequency } \\
\text { Probability }\end{array}$ & $\begin{array}{l}49 \\
0.0265727\end{array}$ & $\begin{array}{l}46 \\
0.0317023\end{array}$ & $\begin{array}{l}3 \\
0.0082873\end{array}$ & $\begin{array}{l}0 \\
0.000000\end{array}$ \\
\hline $2-2.99$ & $\begin{array}{l}\text { Frequency } \\
\text { Probability }\end{array}$ & $\begin{array}{l}60 \\
0.032538\end{array}$ & $\begin{array}{l}56 \\
0.0385941\end{array}$ & $\begin{array}{l}4 \\
0.0110497\end{array}$ & $\begin{array}{l}0 \\
0.000000\end{array}$ \\
\hline $1-1.99$ & $\begin{array}{l}\text { Frequency } \\
\text { Probability } \\
\text { Frequency }\end{array}$ & $\begin{array}{l}6.052530 \\
0.0032538 \\
0\end{array}$ & $\begin{array}{l}6.0505941 \\
0.0041351 \\
0\end{array}$ & $\begin{array}{l}0.0110491 \\
0.0000 \\
0\end{array}$ & $\begin{array}{l}0 \\
0.000000 \\
0\end{array}$ \\
\hline $0-0.99$ & Probability & 0 & 0 & 0 & 0 \\
\hline Sample Size (N) & & 1844 & 1451 & 362 & 32 \\
\hline
\end{tabular}


Table 2: Statistical Parameter Values of RTT data for Different Cases of Received SNR.

\begin{tabular}{|c|c|c|c|c|}
\hline $\begin{array}{l}\text { Statistical } \\
\text { Parameter }\end{array}$ & $\begin{array}{l}\text { ALL RSSI (SNR) } \\
\text { considered }(63 \mathrm{~dB} \geq \\
S N R \geq 13 d B)\end{array}$ & $\begin{array}{lr}\text { Strong } & \text { Signal } \\
\text { (SNR } \quad \geq \\
\text { 25dB) }\end{array}$ & $\begin{array}{l}\text { Grey signal } \\
(25 \mathrm{~dB}>\mathrm{SNR} \geq \\
19 \mathrm{~dB})\end{array}$ & $\begin{array}{l}\text { Weak Signal } \\
(\text { SNR<19dB })\end{array}$ \\
\hline $\bar{N}$ (Sample Size) & 1844 & 1451 & 362 & 32 \\
\hline Mean & 191.96329 & 148.437147 & 351.6677 & 459.9094 \\
\hline Median & 93 & 78.9 & 177.2 & 223.3 \\
\hline Mode & 2.9 & 2.9 & 7.1 & 89.3 \\
\hline Std. Deviation & 403.8951 & 322.1813368 & 586.56516 & 813.6792 \\
\hline Variance & 163131.2 & 103800.814 & 344058.683 & 662073.8 \\
\hline Skewness & 7.442 & 10.331 & 4.497 & 2.857 \\
\hline Kurtosis & 72.012 & 135.857 & 27.134 & 7.299 \\
\hline Range & 5483.5 & 5483.5 & 5038.40 & 3161.8 \\
\hline
\end{tabular}

The highest RTT mean (459.9094ms), standard deviation (813.6792ms) and variance (662073.8) were observed when all signals were weak. From the foregoing, it is clear that RTT increase with decrease in SNR for multiple users on the network. This can be explained as resulting from: (i) the after effect of the selection of lower transmission rates by the error control mechanism which aims to reduce errors in packet transmission as signal becomes weak (ii) longer round trip times of packets to get to and return from their destination due to delays from packet queuing at the WLAN access point for multiple users.

The multiple users on the network increases the aggregate traffic flow on the network thus inducing appreciable longer delays and queuing as well as buffer over flows. (iii) Since RTT also depend on distance and weak signals usually occur at greater distances from the WLAN radio, the increased distance also adds to the increase in RTT.

Fig.1 shows the graph of Standard deviation and Average values of RTT observed for the field data against SNR for multiple users. From the graph of Figure 1, it can be seen that the Average RTT observed for the entire strong signal range is appreciably constant and low $(<150 \mathrm{~ms})$. Also the standard deviation is low for strong signals. Figure 1 also shows the high standard deviation observed for RTT at the transition between strong and Grey signals $(26 \mathrm{~dB}$ to $24 \mathrm{~dB})$. The grey and weak signals also showed a sharp rise in standard deviation at $23 \mathrm{~dB}, 19 \mathrm{~dB}$ and $16 \mathrm{~dB}$.

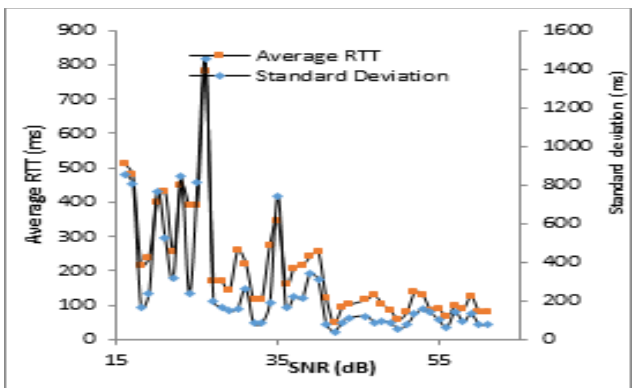

Fig.1 Graph of Standard deviation and Average values of RTT field data against SNR
Development of RTT Probability Models: To develop the models, a normal distribution was assumed for the multiple users RTT field data. From this, a general function for predicting the probability distribution function (PDF) and Cumulative distribution function (CDF) was derived. This was done to obtain RTT values for all the following categories of signal ranges namely (i) All SNR, (ii) Strong signals only (iii) Grey signals only (iv) Weak signals only. According to Ify, (2011), the normal or Gaussian distribution is defined by equation 1 .

$$
f(x)=\frac{1}{\sigma \sqrt{2 \pi}} e^{-\frac{1(x-\mu)^{2}}{2 \sigma^{2}}(-\infty<x<+\infty)} \ldots \ldots 1
$$

Where $\mathrm{x}$ is the variable (RTT) that is to be predicted, $\mu$ is the mean of the population, $\sigma=$ population standard deviation, and. $f(x)$ is the probability distribution function needed to obtain a RTT $=x(m s)$.

The $\mu$ and $\sigma$ are obtained from Table 2, and inserted into equation 1 to obtain the model equations of the probability distribution function presented in equation $2-5$. The range of equations $2-5$ is from 0 to infinity because RTT cannot be negative. The respective equations 2, 3, 4 and 5 give the probability of obtaining a RTT value $=x(m s)$, if (i) SNR is any value (ii) SNR $\geq 25 \mathrm{~dB}$ (Strong signals) (iii) $25 \mathrm{~dB}>\mathrm{SNR} \geq 19 \mathrm{~dB}$ (Grey Signals) (iv) $\mathrm{SNR}<19 \mathrm{~dB}$ (Weak Signals).

Equations 2-5 estimate the probability of obtaining a unique RTT value for the respective SNR category. They do not estimate the probability of obtaining ranges of RTT values hence they are limited in their practical application.

For example, in practical applications, it is of more interest to the researcher or WLAN designer or installer to know the probability that the RTT value falls above or below $5(\mathrm{~ms})$ rather than the probability that it is equal to 5 ( $\mathrm{ms})$. 


$$
\begin{aligned}
& f(x)=0.000987737 e^{-3.06502 \mathrm{E}-06(x-191.96329)^{2}(0<x<\infty)} . .2 \\
& f(x)=0.001238254 e^{-4.81692 \mathrm{E}-06(x-148.437147)^{2}(0<x<\infty) \ldots 3} \\
& f(x)=0.000680133 e^{-1.45324 \mathrm{E}-06(x-351.6677)^{2}(0<x<\infty)} \ldots 4 \\
& f(x)=0.000490294 e^{-7.55203 \mathrm{E}-07(x-459.9094)^{2}(0<x<\infty)} \ldots .5
\end{aligned}
$$

This limitation of the PDF leads to the need to evaluate the CDF in terms of standard units. To do this, equation 1 is transformed to the standard normal form as shown in equation 6 (Ify, 2011).

$$
f(Z)=\frac{1}{\sigma \sqrt{2 \pi}} e^{-{\frac{1(Z)}{2 \sigma^{2}}}^{2}(-\infty<x<+\infty)} \ldots \ldots .6
$$

Where $\mathrm{Z}=\frac{x-\mu}{\sigma}$. .7

Equation 8, 9, 10 and 11 respectively can be used to estimate $\mathrm{Z}$ values for all values of SNR, strong signals, grey signals and weak signals respectively

$$
\begin{aligned}
Z & =\frac{x-191.96329}{403.8951} \quad(0 \leq x \leq \infty) \ldots \ldots \ldots 8 \\
Z & =\frac{x-148.437147}{322.1813368} \quad(0 \leq x \leq \infty) \ldots \ldots 9 \\
Z & =\frac{x-351.6677}{586.56516} \quad(0 \leq x \leq \infty) \ldots \ldots \ldots 10 \\
Z & =\frac{x-459.9094}{813.6792}(0 \leq x \leq \infty) \ldots \ldots \ldots \ldots 11
\end{aligned}
$$

According to Ify (2011) cumulative distribution function $(\mathrm{CDF})$ is given by equation 12

$$
\mathrm{CDF}=\mathrm{F}(\mathrm{Z})=\frac{1}{\sqrt{2 \pi}} \int_{-\infty}^{Z} e^{-\frac{1}{2} u^{2}} d u \ldots \ldots \ldots . .12
$$

For any value of $\mathrm{Z}$ score in equations 8-11, the CDF can be obtained from the table for standard normal distribution. Table 3 shows the unadjusted CDF probability models values obtained using $\mathrm{Z}$ tables, the correction factors introduced and the the adjusted Multiple users RTT CDF probability models values for the different categories of signals.

To estimate the correction factors shown in Table 3, the unadjusted multiple users RTTCDF probability models values obtained from $\mathrm{Z}$ tables were compared with the probability values computed from the original field data presented in Table 1. The correction factors were obtained by subtracting the multiple users RTTCDF probability models values obtained from $\mathrm{Z}$ tables from the original RTT field data probabilities.
Performance Evaluation of Developed Models: The performances of the models were evaluated by comparing the MURTTCDFPM predicted probability values with the multiple users RTT validation data probabilities. By computing the RMS errors, the MURTTCDFPM developed in this work were also compared with existing Single user RTT CDF probability models developed by Oghogho (2019).

This was done for all the signal categories as shown in Table 4. From Table 4, it can be seen that the MURTTCDFPM developed in this work performed better than the existing Single user RTT CDF models as they all showed lower RMS errors.

The MURTTCDFPM values, the existing Oghogho (2019) Single User RTT CDF probability model values and the validation data probabilities were plotted against RTT in Figure 2-5. Plots of the lower sections of the respective graphs are presented below the full sections to provide clearer view of those parts of the respective graphs. From Figure 2-5, the probability of obtaining a high RTT is low when a single user is on the network compared with when there are multiples users on the network. From Table 4, the developed multiple users RTT CDF Probability models gave good performances as they all showed RMS errors $<11.9274495 \%$ observed for the Grey model.

From Table 3, the probability of obtaining a RTT value $<1 \mathrm{~ms}$ is $0 \%$ for multiple users on the network. Also from Table 3, the All SNR, Strong signals, Grey signals and Weak signals Multiple users RTT CDF probability models predicted the probabilities of having a RTT $<6 \mathrm{~ms}$ as $10 \%, 4.6 \%, 3.3 \%$ and $0 \%$ respectively. Thus when signal has become weak, it is very unlikely to have a RTT $<6 \mathrm{~ms}$.

Figures 2-5 along with Table 4 show that the multiple Users RTT probability models developed in this work follow the validation data more closely than the already existing single user RTT probability models, hence justifying the work done to provide the additional models for multiple users in this paper. 
Table 3: RTT Multiple Users CDF Probability Model Values, the Correction Factorsand the Adjusted CDF Probability Model Values.

\begin{tabular}{|c|c|c|c|c|c|c|c|c|}
\hline \multirow[b]{2}{*}{ RTT range (ms) } & \multirow{2}{*}{$\begin{array}{l}\text { Statistical } \\
\text { Parameter }\end{array}$} & \multicolumn{3}{|c|}{ ALL SNR } & \multicolumn{4}{|c|}{ Strong Signals } \\
\hline & & $\begin{array}{l}\text { CDF } \\
\text { Probability } \\
\text { model value } \\
\text { from } Z \text { table }\end{array}$ & $\begin{array}{l}\text { Correction factor } \\
\text { for CDF } \\
\text { Probability } \\
\text { model }(\gamma)\end{array}$ & $\begin{array}{l}\text { Adjusted CDF } \\
\text { Probability } \\
\text { Model values }\end{array}$ & $\begin{array}{l}\text { CDF } \\
\text { Probability } \\
\text { model value } \\
\text { from } \mathrm{Z} \text { table }\end{array}$ & $\begin{array}{l}\text { Correction } \\
\text { for } \\
\text { Probability } \\
\text { model }(\gamma)\end{array}$ & $\begin{array}{r}\text { factor } \\
\text { CDF }\end{array}$ & $\begin{array}{l}\text { Adjusted CDF } \\
\text { Probability } \\
\text { Model values }\end{array}$ \\
\hline$>2000$ & Probability & 0 & +0.008 & 0.008 & 0 & +0.004 & & 0.004 \\
\hline $1000-1999.99$ & Probability & 0.0228 & -0.006 & 0.0168 & 0.0041 & +0.002 & & 0.0061 \\
\hline $500-999.99$ & Probability & 0.2008 & -0.163 & 0.0378 & 0.1338 & -0.11 & & 0.0238 \\
\hline $100-499.99$ & Probability & 0.3674 & +0.05 & 0.4174 & 0.4217 & -0.019 & & 0.4027 \\
\hline $50-99.99$ & Probability & 0.0458 & +0.131 & 0.1768 & 0.0621 & +0.12 & & 0.1821 \\
\hline $20-49.99$ & Probability & 0.0296 & +0.109 & 0.1386 & 0.0337 & +0.114 & & 0.1477 \\
\hline $10-19.99$ & Probability & 0.0072 & +0.059 & 0.0662 & 0.011 & +0.068 & & 0.079 \\
\hline $7-9.99$ & Probability & 0.0036 & +0.022 & 0.0256 & 0.0036 & +0.016 & & 0.0196 \\
\hline $6-6.99$ & Probability & 0 & +0.013 & 0.013 & 0 & +0.016 & & 0.016 \\
\hline $5-5.99$ & Probability & 0 & +0.016 & 0.016 & 0.0036 & +0.015 & & 0.0186 \\
\hline $4-4.99$ & Probability & 0.0036 & +0.019 & 0.0226 & 0 & +0.027 & & 0.027 \\
\hline $3-3.99$ & Probability & 0 & +0.026 & 0.026 & 0 & +0.032 & & 0.032 \\
\hline $2-2.99$ & Probability & 0 & +0.033 & 0.033 & 0 & +0.039 & & 0.039 \\
\hline $1-1.99$ & Probability & 0 & +0.003 & 0.003 & 0.0036 & +0.001 & & 0.0046 \\
\hline \multirow[b]{3}{*}{ RTT range (ms) } & Probability & 0.0036 & -0.0036 & 0 & 0 & 0 & & 0 \\
\hline & $\begin{array}{l}\text { Statistical } \\
\text { Parameter }\end{array}$ & \multicolumn{3}{|c|}{ Grey signals } & \multicolumn{4}{|c|}{ Weak Signals } \\
\hline & & $\begin{array}{l}\text { CDF } \\
\text { Probability } \\
\text { model value } \\
\text { from } \mathrm{Z} \text { table }\end{array}$ & $\begin{array}{l}\text { Correction factor } \\
\text { for } \text { CDF } \\
\text { Probability } \\
\text { model }(\gamma)\end{array}$ & $\begin{array}{l}\text { Adjusted CDF } \\
\text { Probability } \\
\text { Model values }\end{array}$ & $\begin{array}{l}\text { CDF } \\
\text { Probability } \\
\text { model value } \\
\text { from } \mathrm{Z} \text { table } \\
\end{array}$ & $\begin{array}{l}\text { Correction } \\
\text { for } \\
\text { Probability } \\
\text { model }(\gamma)\end{array}$ & $\begin{array}{r}\text { factor } \\
\text { CDF }\end{array}$ & $\begin{array}{l}\text { Adjusted CDF } \\
\text { Probability } \\
\text { Model values }\end{array}$ \\
\hline$>2000$ & Probability & 0.0025 & +0.014 & 0.0165 & 0.0294 & +0.064 & & 0.0934 \\
\hline 1000-1999.99 & Probability & 0.131 & -0.070 & 0.061 & 0.2252 & -0.225 & & 0.0002 \\
\hline $500-999.99$ & Probability & 0.2678 & -0.171 & 0.0968 & 0.2255 & -0.163 & & 0.0625 \\
\hline $100-499.99$ & Probability & 0.2651 & +0.199 & 0.4641 & 0.1899 & +0.2476 & & 0.4375 \\
\hline $50-99.99$ & Probability & 0.0286 & +0.126 & 0.1546 & 0.0215 & +0.229 & & 0.2505 \\
\hline $20-49.99$ & Probability & 0.0173 & +0.088 & 0.1053 & 0.0139 & +0.111 & & 0.1249 \\
\hline $10-19.99$ & Probability & 0.0067 & +0.015 & 0.0217 & 0.0034 & -0.003 & & 0.0004 \\
\hline $7-9.99$ & Probability & 0.0034 & +0.044 & 0.0474 & 0.0035 & +0.028 & & 0.0315 \\
\hline $6-6.99$ & Probability & 0 & 0 & 0 & 0 & 0 & & 0 \\
\hline $5-5.99$ & Probability & 0 & +0.008 & 0.008 & 0 & 0 & & 0 \\
\hline $4-4.99$ & Probability & 0 & +0.006 & 0.006 & 0 & 0 & & 0 \\
\hline $3-3.99$ & Probability & 0 & +0.008 & 0.008 & 0 & 0 & & 0 \\
\hline $2-2.99$ & Probability & 0.0034 & +0.008 & 0.0114 & 0 & 0 & & 0 \\
\hline $1-1.99$ & Probability & 0 & 0 & 0 & 0 & 0 & & 0 \\
\hline $0-0.99$ & Probability & 0 & 0 & 0 & 0.0034 & -0.0034 & & 0 \\
\hline
\end{tabular}

Table 4: RMS Errors for Multiple and Single User RTT CDF Probability Models.

\begin{tabular}{lcccc}
\hline Signal Category & All SNR & Strong Signals & Grey Signals & Weak Signals \\
\hline $\begin{array}{l}\text { Multiple Users RTT CDF Probability } \\
\text { Models RMS error(ms) }\end{array}$ & 0.056884260 & 0.051411599 & 0.119274495 & 0.086100614 \\
$\begin{array}{l}\text { Oghogho 2019 Single User RTT CDF } \\
\text { Probability Models RMS error(ms) }\end{array}$ & 0.233609211 & 0.258315174 & 0.152113002 & 0.108517477 \\
\hline
\end{tabular}

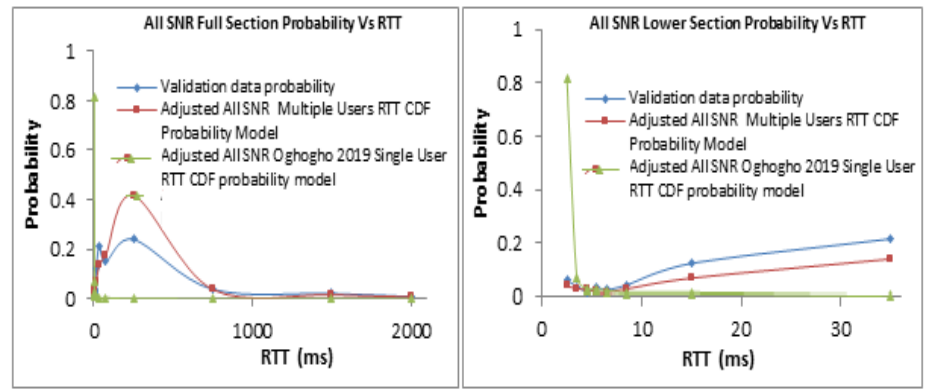

Fig. 2: All SNR RTT CDF Probability models values and validation data Vs RTT
Conclusion: Multiple users RTT Cumulative distribution function probability Models have been developed, validated and compared with already existing similar Single user RTT CDF models in this work. For a given category of SNR, the models can directly predict the probability that RTT will fall into a specific RTT range. The probability models showed low RMS errors $(<11.9274495 \%)$ when compared 
with validation data. They also performed better than similar existing single User RTT CDF probability models when their RMS errors were compared. The models will provide additional information needed by WLAN designers and installers for making better network design and installation decisions.

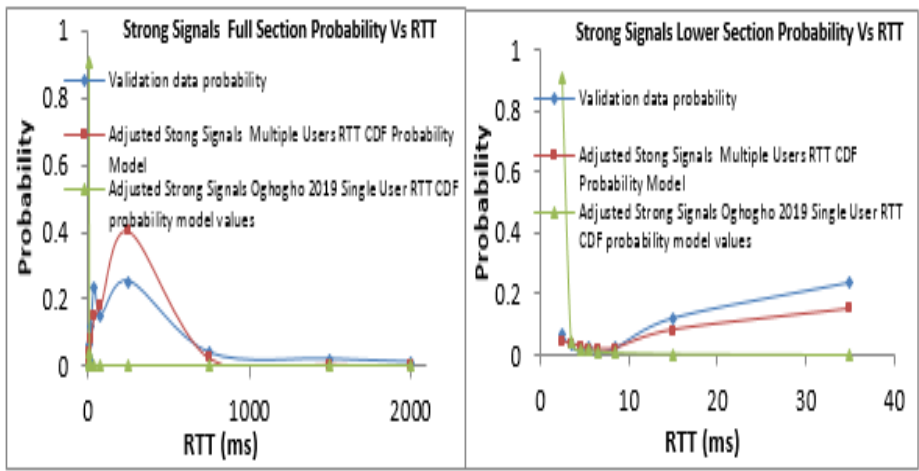

Fig. 3: Strong Signals RTT CDF Probability models values and validation data Vs RTT

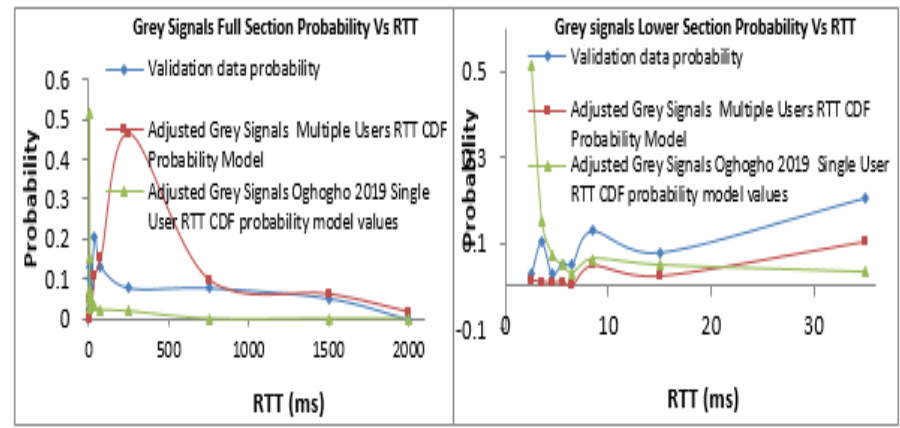

Fig. 4: Grey Signals RTT CDF Probability models values and validation data Vs RTT

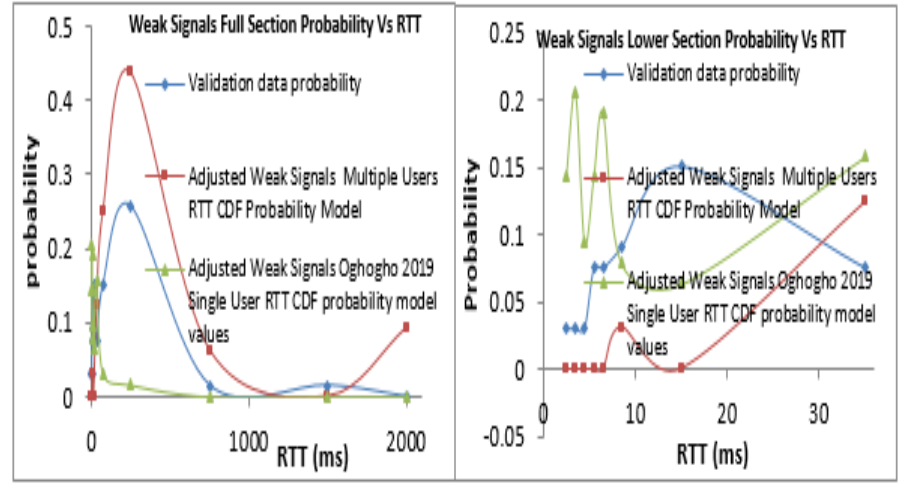

Fig. 5: Weak Signals RTT CDF Probability models values and validation data Vs RTT

Acknowledgement: The contributions of Prof. F.O. Edeko and Prof. J.O. Emagbetere are deeply acknowledged.

\section{REFERENCES}

Domenico D., Stefan M., (2011). CAESAR: Carrier Sense-Based

Ranging in Off-TheShelf802.11 Wireless LAN. ACM CoNEXT 2011, December 6-9 2011, Tokyo, Japan, pp 112.

El Miloud A R., Kamal G., Koutaiba A., Otman E M., Slimane M., (2013). Performance Analysis of Round Trip Delay Time in Practical Wireless Network for Telemanagement. Inter. $J$. Elect. Rob. Electro. Comm. Engineer. 7 (11) 933-939

Geier J., (2008a). Wi-Fi: Define Minimum SNR Values for Signal Coverage. Enterprise Networking Planet. Retrieved 4/04/13

http://www.enterprisenetworkingp lanet.com/netsp/article.php/37476 56/WiFi-Define-Minimum-SNR-

Values-for-Signal-Coverage.htm

Geier J., (2008b). How to: Conduct a Wireless Site Survey. Wi-fi Planet. Retrieved 29/07/14 at http://www.wi-

fiplanet.com/tutorials/article.php/3 761356

Kavidha V., Sadasivam V., (2010). Exploring Round Trip Time fairness for Adaptive Layered Transmission Control Protocol. Int. J. Adv. Networking Applica. 1 (6): 353-358

Li H., Xiong N., Park J.H., Cao, Q. (2009). Predictive control for vehicular sensor networks based on round-trip-time-delay prediction. IET Commun.4 (7). 801-809

Nafei Z., Jingsha H., Yue Z., Wei W., (2013). On the Accuracy of Packet Delay Estimation in Distributed Service Networks. $J$ NetwSyst Manage 21:623-649. 
Oghogho (2019) Single user Round Trip Time Probability Models in IEEE802.11b WLANS. $J$. Research and Innovation in. Engineering. Vol4. In press

Oghogho (2018) Single user Round Trip Time Models in IEEE802.11b WLANS. J. Research and Innovation in. Engineering. 3 (2) 24-29.

OghoghoI. (2017). Throughput dependence on SNR in IEEE 802.11 WLAN systems. In Ed. Mehdi Khosrow-Pour. Encyclopaedia of Information Science and Technology, Fourth Edition. IGI Global USA. pp 6618-6629; DOI: 10.4018/978-15225-2255-3.ch574, ISBN 9781522522553 (set: hardcover) I ISBN 9781522522560 (ebook).

Oghogho I., Fredrick, O E., \& Joy, E. (2018). Measurement and Modelling of TCP Downstream Throughput Dependence on SNR in an IEEE 02.11b WLAN System. J. King Saud University-Engineering. Sci. 30: 170-176.

Oghogho I., Fredrick, O E., \& Joy, E. (2017). Empirical Investigation on the Dependence of TCP Downstream Throughput on SNR in an IEEE802. 11b WLAN System. . J. King Saud University-Engineering. Sci. 29: 135-143.

Oghogho I., Fredrick, O E., \& Joy, E. (2015a). Probability Models for Predicting TCP Upstream Throughput in an IEEE802.11b WLAN System. J. of Electrical and Electronic. Engineering. 12 (2) 1-19.
Oghogho I., Fredrick, O E., Joy, E., (2015b) Investigation on the Dependence of TCP Upstream Throughput on SNR For Single and Multiple Links in a WLAN System. Review of Information Engineering and Applications. 2(1): 15-32.

Oghogho, I., Edeko, F O., Emagbetere, J E., \& Victor, M. (2014a). Empirical investigation on the dependence of TCP upstream throughput on SNR in an IEEE802. 11b WLAN system. In Telecommunications (ICT), $2014 \quad 21$ st International Conference on (pp. 442-446). IEEE. Doi:10.1109/ICT.2014.6845155

Oghogho I., Fredrick, O E., Joy, E., (2014b). Empirical Probability Models for Predicting TCP Downstream throughput in a WLAN System. ISTP J. Research in Electrical and Electronic Engineering Special issue. 38-48.

Stephen D. F., (2013). Passively Measuring TCP Round-Trip Times. Communications of the ACM56 (10), doi:10.1145/2507771.2507781

Wu F., Tang B., Liu Y., Zhang L. (2011) Throughput Model of IEEE 802.11 DCF Considering MultiMate Procedia Environ. Sci. 11 493-498.

Zobenko A., Scherrer T., Soo-Yong K. Proximity estimation for location-based services with roundtrip time. Electronic Letters 50 (14) 1029-1031. 